\section{Reductive Dimerization and Thermal Rearrangement of Biphenylene Coordinated to Tricarbonylmanganese}

Sodio C. N. Hsu and Wen-Yann Yeh*

Department of Chemistry

National Sun Yat-Sen University

Kaohsiung, Taiwan 804

Gene-Hsiang Lee and Shie-Ming Peng ${ }^{\dagger}$

Department of Chemistry

National Taiwan University

Taipei, Taiwan 106

Received August 4, 1998

$[N]$-phenylenes are comprised of alternating benzene and cyclobutadiene rings. ${ }^{1}$ The unique feature of $[N]$-phenylenes is their strained four-membered rings, which has attracted the attention of theoretical and experimental chemists recently. ${ }^{2}$ The parent biphenylene $\left[\left(\mathrm{C}_{6} \mathrm{H}_{4}\right)_{2}\right]$ was known for many years. ${ }^{3}$ Theoretical calculations suggest that biphenylene has a relatively low resonance energy of about $15 \mathrm{kcal} / \mathrm{mol},{ }^{4}$ whereas its strain energy is high, about $65 \mathrm{kcal} / \mathrm{mol} .{ }^{5}$ Thus, previous studies of the activation of biphenylene by iron, ${ }^{6}$ cobalt, ${ }^{7}$ and nickel ${ }^{8}$ group complexes have led to metal insertion into the central ring to form a dibenzo(metallacyclopentadiene) species. It is well-established that arenes are activated toward nucleophiles or chemical reduction by coordination to the $\left[\mathrm{Cr}(\mathrm{CO})_{3}\right]$ and $\left[\mathrm{Mn}(\mathrm{CO})_{3}\right]^{+}$units. ${ }^{9} \mathrm{We}$ therefore prepared $\left[\left(\eta^{6}-\mathrm{C}_{12} \mathrm{H}_{8}\right) \mathrm{Mn}(\mathrm{CO})_{3}\right]^{+}\left[\mathrm{BF}_{4}\right]^{-}\left(\mathbf{1}^{+} \mathrm{BF}_{4}^{-}\right)^{10}$ in $87 \%$ yield by direct treatment of biphenylene with $\left[\mathrm{Mn}(\mathrm{CO})_{5}\right]^{+}-$ $\left[\mathrm{BF}_{4}\right]^{-11}$ in hot $\mathrm{CH}_{2} \mathrm{Cl}_{2}$. Herein we report that reduction of $\mathbf{1}^{+}$ affords the dimer $\left[\left(\left(\eta^{5}-\mathrm{C}_{6} \mathrm{H}_{4}\right) \mathrm{C}_{6} \mathrm{H}_{4}\right) \mathrm{Mn}(\mathrm{CO})_{3}\right]_{2}$ (2), which upon heating rearranges to yield the unprecedented di(benzopentalene) complex $\left[\left(\eta^{5}-\mathrm{C}_{5}\left(\mathrm{C}_{4} \mathrm{H}_{4}\right)\left(\mathrm{C}_{3} \mathrm{H}_{4}\right)\right) \mathrm{Mn}(\mathrm{CO})_{3}\right]_{2}$ (3) (Scheme 1).

\footnotetext{
* Author for correspondence.

$\dagger$ To whom inquiries concerning the X-ray crystallographic work should be addressed.

(1) Vollhardt, K. P. C. Pure Appl. Chem. 1993, 65, 153.

(2) (a) Schulman, J. M.; Disch, R. L. J. Am. Chem. Soc. 1996, 118, 8470

(b) Toda, F.; Garratt, P. Chem. Rev. 1992, 92, 1685 and references therein.

(3) (a) Cohen, S. G.; Massey, A. G. J. Organomet. Chem. 1967, 10, 471. (b) Gardner, S. A.; Gordon, H. B.; Rausch, M. D. J. Organomet. Chem. 1973, 60, 179. (c) Usón, R.; Vicente, J.; Cirac, J. A.; Chicote, M. T. J. Organomet. Chem. 1980, 198, 105. (d) Cornioley-Deuschel, C.; von Zelewsky, A. Inorg. Chem. 1987, 26, 3354. (e) Becker, S.; Fort, Y.; Vanderesse, R.; Caubere, P. J. Org. Chem. 1989, 54, 4848 .
}

(4) (a) Cass, R. C.; Springall, H. D.; Quincey, P. G. J. Chem. Soc. 1955 1188. (b) Dewer, M. J. S. The Molecular Orbital Theory of Organic Chemistry; McGraw-Hill: New York, 1969.

(5) Cava, M. P.; Mitchell, M. J. Cyclobutadienes and Related Compounds; Academic Press: New York, 1967.

(6) Yeh, W,-Y.; Hsu, S. C. N.; Peng, S.-M.; Lee, G.-H. Organometallics 1998, 17, 2477.

(7) (a) Perthuisot, C.; Jones, W. D. J. Am. Chem. Soc. 1994, 116, 3647 (b) Perthuisot, C.; Edelbach, B. L.; Zubris, D. L.; Jones, W. D. Organometallics 1997, 16, 2016. (c) Lu, Z.; Jun, C.-H.; de Gala, S. R.; Sigalas, M. P.; Eisenstein, O.; Crabtree, R. H. Organometallics 1995, 14, 1168.

(8) (a) Eisch, J. J.; Piotrowski, A. M.; Han, K. I.; Krüger, C.; Tsay, Y. H. Organometallics 1985, 4, 224. (b) Edelbach, B. L.; Lachicotte, R. J.; Jones, W. D. J. Am. Chem. Soc. 1998, 120, 2843.

(9) (a) Renard, C.; Valentic, R.; Rose-Munch, F.; Rose, E.; Vaisserman, J. Organometallics 1998, 17, 1587. (b) Dullaghan, C. A.; Carpenter, G. B Sweigart, D. A.; Choi, D. S.; Lee, S. S.; Chung, Y. K. Organometallics 1997, 16, 5688. (c) Sun, S.; Dullaghan, C. A.; Sweigart, D. A. J. Chem. Soc., Dalton Trans. 1996, 4493 and references therein. (d) Sun, S.; Yeung, L. K.; Sweigart, D. A.; Lee, T.-Y.; Lee, S. S.; Chung, Y. K.; Switzer, S. R.; Pike, R. D. Organometallics 1995, 14, 2613. (e) Whiteley, M. W. In Comprehensive Organometallic Chemistry II; Pergamon: Oxford, U.K., 1995; Vol. 5, p 331 (f) McDaniel, K. F. In Comprehensive Organometallic Chemistry II; Pergamon: Oxford, U.K., 1995; Vol. 6, p 93. (g) Beck, W.; Niemer, B.; Wieser, M. Angew. Chem., Intl. Ed. Engl. 1993, 32, 923. (h) Thompson, R. L.; Lee S.; Rheingold, A. L.; Cooper, N. J. Organometallics 1991, 10, 1657. (i) Corella J. A.; Cooper, N. J. J. Am. Chem. Soc. 1990, 112, 2832.

(10) The IR, NMR, and crystallographic data agree with those previously reported by Sweigart and co-workers for $\mathbf{1}^{+} \mathrm{BF} 4^{-}$resulting from substitution of the naphthalene ligand in $\left[\left(\eta^{6} \text {-naphthalene }\right) \mathrm{Mn}(\mathrm{CO})_{3}\right]^{+}[\mathrm{BF} 4]^{-}$by biphenylene. See: Dullaghan, C. A.; Carpenter, G. B.; Sweigart, D. A. Chem. Eur. J. 1997, 3, 75.
Scheme 1

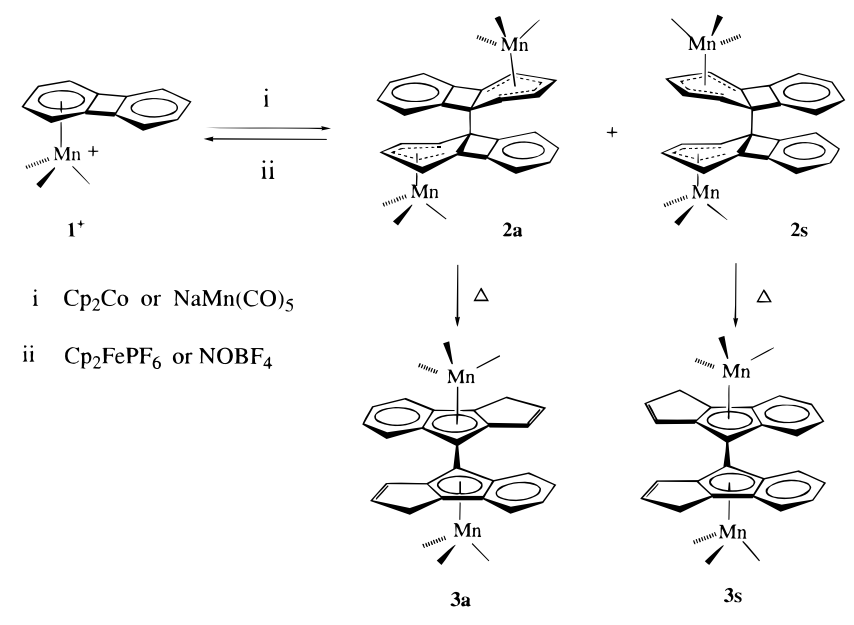

In a typical reaction, a $\mathrm{CH}_{2} \mathrm{Cl}_{2}$ solution of $\mathbf{1}^{+} \mathrm{BF}_{4}^{-}(200 \mathrm{mg}$, $0.53 \mathrm{mmol}$ ) and an equimolar solution of cobaltocene were stirred at ambient temperature for $30 \mathrm{~min} .{ }^{12}$ Two complexes, syn- $\left[\left(\left(\eta^{5}-\right.\right.\right.$ $\left.\left.\left.\mathrm{C}_{6} \mathrm{H}_{4}\right) \mathrm{C}_{6} \mathrm{H}_{4}\right) \mathrm{Mn}(\mathrm{CO})_{3}\right]_{2}(2 \mathrm{~s})$ and anti- $\left[\left(\left(\eta^{5}-\mathrm{C}_{6} \mathrm{H}_{4}\right) \mathrm{C}_{6} \mathrm{H}_{4}\right) \mathrm{Mn}(\mathrm{CO})_{3}\right]_{2}$ (2a), ${ }^{13}$ in an approximate 1:1 ratio were isolated in $82 \%$ yield after chromatography on silica gel with a $\mathrm{CH}_{2} \mathrm{Cl}_{2} / n$-hexane (1:4, $\mathrm{v} / \mathrm{v})$ eluant. Presumably, initial reduction occurs at the manganese center of $\mathbf{1}^{+}$to generate an $\left.\left[\eta^{5}-\mathrm{C}_{12} \mathrm{H}_{8}\right) \mathrm{Mn}(\mathrm{CO})_{3}\right]$ radical $^{14}$ in either enantiomeric form (Chart 1), and cross dimerization of which affords the diastereomers $\mathbf{2} \mathbf{s}$ and $\mathbf{2 a}$. An alternative pathway via an anion/cation addition route, established for the conversion of $\left[\mathrm{Mn}(\mathrm{CO})_{3}\left(\eta^{6}-\mathrm{C}_{6} \mathrm{H}_{6}\right)\right]^{+}$into $\left[\left(\mathrm{Mn}(\mathrm{CO})_{3}\right)\right]_{2}\left(\eta^{5}, \eta^{5}-\mathrm{C}_{12} \mathrm{H}_{12}\right),{ }^{15}$ is also plausible. It is interesting that $\mathrm{Mn}(\mathrm{CO})_{5}{ }^{-}$reduces $\mathbf{1}^{+}$to give $2(\mathrm{~s}$ + a) and $\mathrm{Mn}_{2}(\mathrm{CO})_{10}$, whereas the organic nucleophiles, $\mathrm{R}^{-}=$ $\mathrm{H}^{-}, \mathrm{Me}^{-}$, and $\mathrm{Me}_{3} \mathrm{CC}(\mathrm{O}) \mathrm{CH}_{2}^{-}$, were found to attack $\mathbf{1}^{+}$at a bridgehead carbon, forming $\left(\left(\eta^{5}-\mathrm{C}_{6} \mathrm{H}_{4} \mathrm{R}\right) \mathrm{C}_{6} \mathrm{H}_{4}\right) \mathrm{Mn}(\mathrm{CO})_{3} \cdot{ }^{10}$ Furthermore, treatment of $\mathbf{2} \mathbf{s}$ (and $\mathbf{2 a}$ ) with the oxidizing agent, $\left(\mathrm{Cp}_{2^{-}}\right.$ $\mathrm{Fe}) \mathrm{PF}_{6}$ or $\mathrm{NOBF}_{4}$, in $\mathrm{CH}_{2} \mathrm{Cl}_{2}$ at $25^{\circ} \mathrm{C}$ reforms $\mathbf{1}^{+}$in high yields

(11) (a) Jackson, J. D.; Villa, S. J.; Bacon, D. S.; Pike, R. D. Organomet aliics 1994, 13, 3972. (b) Mews, R. Angew. Chem., Intl. Ed. Engl. 1975, 14 640. (c) Schmidt, S. P.; Nitschze, J.; Trogler, W. C. Inorg. Synth. 1989, 26, 113

(12) Cyclic voltammetric investigations of $\mathbf{1}^{+} \mathrm{BF}^{-}\left(1 \mathrm{mM}\right.$ in $\left.\mathrm{CH}_{3} \mathrm{CN}\right)$ at $25^{\circ} \mathrm{C}$ showed an irreversible reduction potential at $-896 \mathrm{mV}$ and an irreversible oxidation potential at $+1319 \mathrm{mV}$ (vs $\mathrm{Ag} / \mathrm{AgCl}$ ) with $\mathrm{Bu}_{4} \mathrm{NPF}_{6}$ $(0.1 \mathrm{M})$ as supporting electrolyte, a $\mathrm{Pt}$ button working electrode, and a $\mathrm{Pt}$ wire auxiliary electrode.

(13) The symbols, syn and anti, indicate the positions of the two phenyl groups in the same and opposite sides of the complex, respectively, with the two central four-membered rings being trans to each other. $2 \mathrm{~s}$ : mass spectrum (electron impact, EI), $m / z 582\left(\mathrm{M}^{+}\right), 582-28 n(n=1-6)$; IR ( $n$-hexane, $\left.v \mathrm{CO}\right)$, 2012 (s), 1960 (s), 1944 (s) cm ${ }^{-1},{ }^{1} \mathrm{H}$ NMR (acetone- $\left.d_{6}, 20{ }^{\circ} \mathrm{C}\right), \delta 3.21$ (d, J $=6.9 \mathrm{~Hz}, 1 \mathrm{H}), 4.97(\mathrm{~m}, 1 \mathrm{H}), 5.47(\mathrm{~d}, J=2.4 \mathrm{~Hz}, 2 \mathrm{H}), 7.15-7.38(\mathrm{~m}, 3 \mathrm{H})$ $7.59(\mathrm{~d}, J=7.5 \mathrm{~Hz}, 1 \mathrm{H}) ;{ }^{13} \mathrm{C}\left\{{ }^{1} \mathrm{H}\right\}$ NMR (acetone- $\left.d_{6}, 20{ }^{\circ} \mathrm{C}\right), \delta 59.0,61.8$, 78.3, 83.0, 85.9, 97.4, 119.9, 123.4, 127.4, 130.2, 147.6, 155.5, 223.3 (CO). Anal. Calcd for $\mathrm{C}_{30} \mathrm{H}_{16} \mathrm{O}_{6} \mathrm{Mn}_{2}$ : C, 61.88; H, 2.77. Found: C, 61.80; H, 2.75. 2a: mass spectrum (EI), $m / z$ 582 $\left(\mathrm{M}^{+}\right), 582-28 n(n=1-6)$; IR ( $n$-hexane $\nu \mathrm{CO}$ ), 2012 (s), 1960 (s), 1944 (s) $\mathrm{cm}^{-1} ;{ }^{1} \mathrm{H}$ NMR (acetone- $d_{6}, 20{ }^{\circ} \mathrm{C}$ ), $4.42(\mathrm{~d}, J=6.6 \mathrm{~Hz}, 1 \mathrm{H}), 5.15(\mathrm{~d}, J=4.8 \mathrm{~Hz}, 1 \mathrm{H}), 5.36(\mathrm{t}, J=6.6 \mathrm{~Hz}, 1 \mathrm{H})$, $5.54(\mathrm{t}, J=4.8 \mathrm{~Hz}, 1 \mathrm{H}), 6.66(\mathrm{~d}, J=7.5 \mathrm{~Hz}, 1 \mathrm{H}), 6.95(\mathrm{~d}, J=7.5 \mathrm{~Hz}, 1 \mathrm{H})$, $6.97(\mathrm{t}, J=7.5 \mathrm{~Hz}, 1 \mathrm{H}), 7.26(\mathrm{t}, J=7.5 \mathrm{~Hz}, 1 \mathrm{H}) ;{ }^{13} \mathrm{C}\left\{{ }^{1} \mathrm{H}\right\}$ NMR (acetone$\left.d_{6}, 20^{\circ} \mathrm{C}\right), \delta 60.9,61.6,79.2,84.7,85.6,97.9,119.9,123.3,126.6,130.1$, 147.1, 156.5, 223.8 (CO). Anal. Calcd for $\mathrm{C}_{30} \mathrm{H}_{16} \mathrm{O}_{6} \mathrm{Mn}_{2}$ : C, 61.88; H, 2.77. Found: C, 61.76; H, 2.80.

(14) The radical coupling mechanism has been proposed for reductive dimerization of $\left[\mathrm{CpFe}\left(\eta^{6}-\mathrm{C}_{6} \mathrm{H}_{6}\right)\right]^{+}$to $\left[\mathrm{CpFe}\left(\eta^{5}-\mathrm{C}_{6} \mathrm{H}_{6}\right)\right]_{2}$. (a) Nesmayanov, $\mathrm{A}$ N.; Vol'Kenau, N. A.; Petrakova, V. A. J. Organomet. Chem. 1977, 136, 363. (b) Hamon, J.-R.; Astruc, D.; Michaud, P. J. Am. Chem. Soc. 1981, 103, 758. (c) Rasjasekharan, M. V.; Giezynski, S.; Ammeter, J. H.; Oswald, N.; Michaud, P.; Hamon, J.-R.; Astruc, D. J. Am. Chem. Soc. 1982, 104, 2400. (d) Pearson, A. J.; Chen, Y.-S.; Daroux, M. L.; Tanaka, A. A.; Zettler, M. J. Chem. Soc., Chem. Commun. 1987, 155. (e) Astruc, D. Electron Transfer and Radical Processes in Transition-Metal Chemistry; VCH: Weinheim, 1995.

(15) Lee, S.; Lovelace, S. R.; Arford, D. J.; Geib, S. J.; Weber, S. G.; Cooper, N. J. J. Am. Chem. Soc. 1996, 118, 4190. 


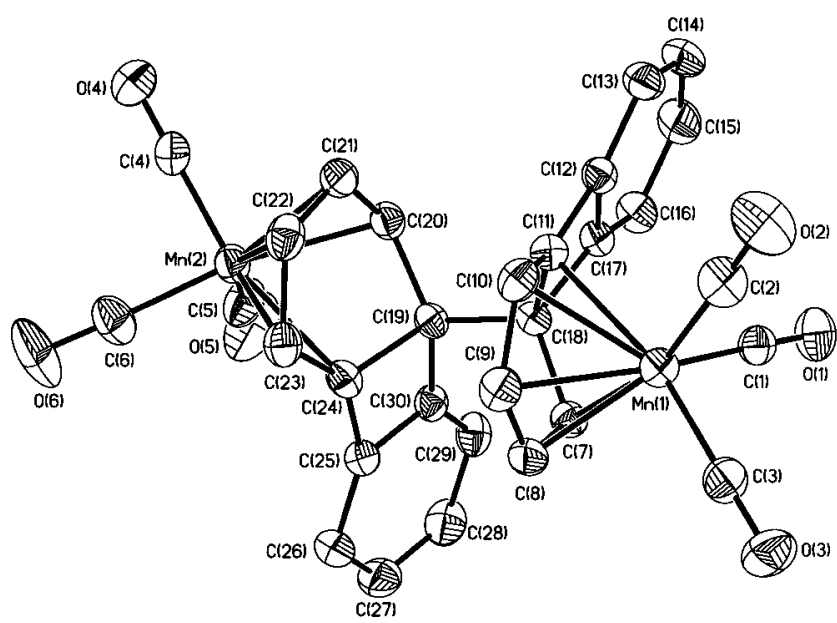

Figure 1. Molecular structure of 2 s. The hydrogen atoms have been artificially omitted for clarity.

\section{Chart 1}
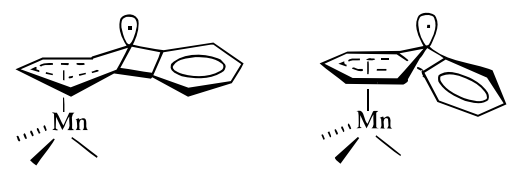

$(70-75 \%)$ after purification. Reductive dimerization of ligated arenes is well documented, ${ }^{9 c, 16}$ while the reversed oxidative $\mathrm{C}-\mathrm{C}$ cleavage of their dimers is seldom recorded. ${ }^{17}$

The ORTEP diagram of $2 \mathrm{~s}$ is shown in Figure 1. The structure consists of a discrete molecule with each manganese atom bonded to three terminal carbonyls and a cyclohexadienyl group. The pentadienyl units $(\mathrm{C} 7-\mathrm{C} 11$ and $\mathrm{C} 20-\mathrm{C} 24)$ and the benzocyclobutane units $(\mathrm{C} 11-\mathrm{C} 18$ and $\mathrm{C} 19, \mathrm{C} 24-\mathrm{C} 30)$ are each planar to within $0.04 \AA$. The bridging $\mathrm{C} 18$ and $\mathrm{C} 19$ atoms are displaced from the pentadienyl planes exo to $\mathrm{Mn}$. The dihedral angles between the $(\mathrm{C} 7-\mathrm{C} 11)$ and $(\mathrm{C} 7, \mathrm{C} 18, \mathrm{C} 11)$ planes is $41.5^{\circ}$, and between the $(\mathrm{C} 7, \mathrm{C} 18, \mathrm{C} 11)$ and $(\mathrm{C} 11, \mathrm{C} 12, \mathrm{C} 17, \mathrm{C} 18)$ planes is $51.3^{\circ}$. The pentadienyl carbons are bonded to the manganese atoms asymmetrically, with the $\mathrm{Mn}-\mathrm{C}$ distances in the range 2.275(3)-2.130(4) $\AA$ to Mn1 and 2.307(3)-2.113(3) $\AA$ to Mn2. The benzene $\mathrm{C}-\mathrm{C}$ bonds are delocalized, $1.36 \pm 0.02 \AA$.

It is apparent that the central rings in $\mathbf{2}$ remain strained. ${ }^{18}$ Thus, heating $\mathbf{2 s}$ and $\mathbf{2 a}$ in refluxing $n$-octane $\left(125^{\circ} \mathrm{C}\right)$ affords syn$\left[\left(\eta^{5}-\mathrm{C}_{5}\left(\mathrm{C}_{4} \mathrm{H}_{4}\right)\left(\mathrm{C}_{3} \mathrm{H}_{4}\right)\right) \mathrm{Mn}(\mathrm{CO})_{3}\right]_{2} \quad(3 \mathbf{s})$ and anti- $\left[\left(\eta^{5}-\mathrm{C}_{5}\left(\mathrm{C}_{4} \mathrm{H}_{4}\right)-\right.\right.$ $\left.\left.\left(\mathrm{C}_{3} \mathrm{H}_{4}\right)\right) \mathrm{Mn}(\mathrm{CO})_{3}\right]_{2}(\mathbf{3 a}),{ }^{19}$ respectively, in $71 \%$ yield after purification by TLC on silica gel eluting with $\mathrm{CH}_{2} \mathrm{Cl}_{2} / n$-hexane (1:4, $\mathrm{v} / \mathrm{v})$. In this reaction the organic ligand has rearranged to form a di(benzopentalene) species, ${ }^{20}$ and the $\mathrm{Mn}(\mathrm{CO})_{3}$ groups have shifted to bind the middle cyclopentadienyl rings. Compounds 3s and 3a are not interconvertible. The regiospecific and stereospecific conversion from $\mathbf{2}$ to $\mathbf{3}$ implies a metal-mediated pathway (Scheme 2). The involvement of an $\mathrm{HMn}($ diene $)(\mathrm{CO})_{3}$ inter-

(16) (a) Thompson, R. L.; Geib, S. J.; Cooper, N. J. J. Am. Chem. Soc. 1991, 113, 8961. (b) Gaudet, M. V.; Hanson, A. W.; White, P. S.; Zaworotko M. J. Organometallics 1989, 8, 286. (c) Astruc, D. Chem. Rev. 1988, 88 , 1189. 45

(17) Moinet, C.; Roman, E.; Astruc, D. J. Organomet. Chem. 1977, 128,

(18) The ring strain is evidenced by the bond angles in $\mathbf{2 s}$ : C7-C18$\mathrm{C} 11=102.3(3)^{\circ}, \mathrm{C} 20-\mathrm{C} 19-\mathrm{C} 24=101.7(3)^{\circ}, \mathrm{C} 11-\mathrm{C} 18-\mathrm{C} 17=83.9(2)^{\circ}$, and $\mathrm{C} 24-\mathrm{C} 19-\mathrm{C} 30=83.9(2)^{\circ}$ by comparing with those angles in free biphenylene $\left(122.6^{\circ}\right.$ and $\left.90^{\circ}\right)$ and in $\mathbf{1}^{+}\left(122.3^{\circ}\right.$ and $\left.89.3^{\circ}\right)$.

(19) 3s: mass spectrum (EI), m/z $582\left(\mathrm{M}^{+}\right), 582-28 n(n=1-6)$; IR ( $n-$ hexane, $\nu \mathrm{CO}$ ), $2016(\mathrm{~s}), 1948(\mathrm{vs}) \mathrm{cm}^{-1} ;{ }^{1} \mathrm{H}$ NMR (acetone- $d_{6}, 20{ }^{\circ} \mathrm{C}$ ), $\delta$ $3.85(\mathrm{~s}, 4 \mathrm{H}), 6.84(\mathrm{br}, 2 \mathrm{H}), 7.00-7.50(\mathrm{~m}, 8 \mathrm{H}), 7.92(\mathrm{~d}, J=9.0 \mathrm{~Hz}, 2 \mathrm{H})$ Anal. Calcd for $\mathrm{C}_{30} \mathrm{H}_{16} \mathrm{O}_{6} \mathrm{Mn}_{2}$ : C, 61.88; H, 2.77. Found: C, 61.66; H, 2.83. 3s: mass spectrum (EI), $m / z 582\left(\mathrm{M}^{+}\right), 582-28 n(n=1-6)$; IR ( $n$-hexane, $\nu \mathrm{CO}$ ), 2016 (s), 1950 (vs) $\mathrm{cm}^{-1}$; ${ }^{1} \mathrm{H}$ NMR (acetone- $d_{6},-60{ }^{\circ} \mathrm{C}$ ), $\delta 3.79(\mathrm{~s}$ $2 \mathrm{H}), 3.86(\mathrm{~s}, 2 \mathrm{H}), 6.51(\mathrm{~d}, J=4.5 \mathrm{~Hz}, 1 \mathrm{H}), 6.69(\mathrm{~d}, J=4.8 \mathrm{~Hz}, 1 \mathrm{H}), 6.95$ $(\mathrm{d}, J=4.8 \mathrm{~Hz}, 1 \mathrm{H}), 7.10(\mathrm{~d}, J=5.1 \mathrm{~Hz}, 1 \mathrm{H}), 7.22(\mathrm{t}, J=7 \mathrm{~Hz}, 1 \mathrm{H}), 7.37$ $(\mathrm{t}, J=6.9 \mathrm{~Hz}, 1 \mathrm{H}), 7.44(\mathrm{~m}, 2 \mathrm{H}), 7.53(\mathrm{t}, J=7.4 \mathrm{~Hz}, 1 \mathrm{H}), 7.95(\mathrm{~d}, J=8.7$ $\mathrm{Hz}, 1 \mathrm{H}), 8.02(\mathrm{~d}, J=8.1 \mathrm{~Hz}, 1 \mathrm{H}), 8.13(\mathrm{~d}, J=8.7 \mathrm{~Hz}, 1 \mathrm{H})$.

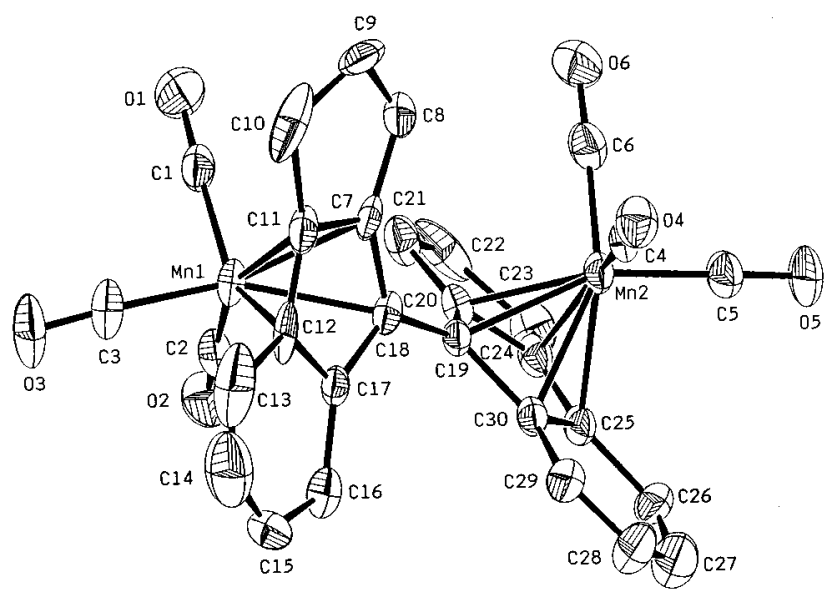

Figure 2. Molecular structure of 3s. The hydrogen atoms have been artificially omitted for clarity.

Scheme 2

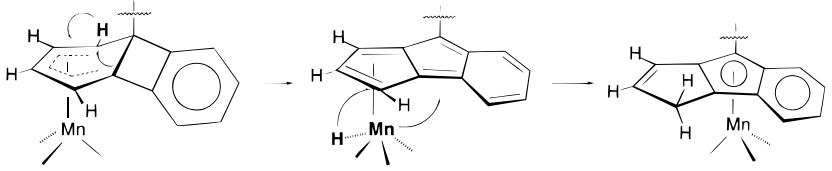

mediate has been proposed to account for the hydrogen migration in $\left(\eta^{5}\right.$-cyclohexadienyls $) \mathrm{Mn}(\mathrm{CO})_{3}{ }^{21}$ Nevertheless, a concerted process via a $\mathrm{C}-\mathrm{C}$ bond migration, a [1,4]-hydrogen shift, and slippage of the $\mathrm{Mn}(\mathrm{CO})_{3}$ group cannot be excluded at this stage.

The ORTEP diagram of $\mathbf{3 s}$ is shown in Figure 2. Each manganese atom is linked to three terminal carbonyls and a cyclopentadienyl ligand. The two benzopentalene units $\mathrm{C} 7-\mathrm{C} 18$ and $\mathrm{C} 19-\mathrm{C} 30$ are each planar, with the averaged atomic displacement from plane being $0.04 \AA$, and the dihedral angle between the two planes is $53.5^{\circ}$. The $\mathrm{C} 19-\mathrm{C} 20$ length is 1.484 (9) $\AA$, characteristic of $s p^{2} \mathrm{C}-\mathrm{C}$ single bonds. The cyclopentadienyl carbons are bonded to the manganese atom about equally, being $2.17 \pm 0.02 \AA$. The short C8-C9 (1.34(1) $\AA$ ) and C21$\mathrm{C} 22$ (1.41(1) $\AA$ ) lengths could indicate the positions of $\mathrm{C}-\mathrm{C}$ double bonds in the external cyclopentadiene rings. The benzene $\mathrm{C}-\mathrm{C}$ distances are localized, ranging from 1.30(2) through 1.45(1) $\AA$, implying little aromaticity of the rings.

In summary, the transformation from $\mathbf{1}^{+}$to $\mathbf{3}$ is of interest within the context of the chemistry of phenylenes ${ }^{1,2}$ and pentalenes $^{22}$ and of the ability of a transition-metal center to promote these reactions. It may provide an attractive general strategy for the activation of larger $[N]$-phenylenes $(N \geq 3)$ which are applicable to organic synthesis. ${ }^{23}$ Further investigation is in progress in our laboratory.

Acknowledgment. This research was supported by the National Science Council of Taiwan.

Supporting Information Available: Complete tables of crystallographic data, positional parameters, anisotropic thermal parameters, bond angles, and bond distances of $2 \mathbf{s}$ and $3 \mathbf{s}$ (14 pages, print/PDF). See any current masthead page for ordering information and Web access instructions.

\section{JA982773H}

(20) Flash vacuum pyrolysis of organic biphenylene $\left(900{ }^{\circ} \mathrm{C} / 0.02\right.$ Torr $)$ has been shown to yield benzopentalene, which dimerizes readily and adds cyclopentadiene above $-70^{\circ} \mathrm{C}$. See: Brown, R. F. C.; Choi, N.; Coulston, K. J.; Eastwood, F. W.; Wiersum, U. E.; Jenneskens, L. W. Tetrahedron Lett. 1994, 35, 4405 .

(21) (a) Lamanna, W.; Brookhart, M. J. Am. Chem. Soc. 1980, 102, 3490 (b) Munro, G. A. M.; Pauson, P. L. J. Chem. Soc., Chem. Commun. 1976, 134

(22) (a) Zhao, S.; Mehta, G.; Helquist, P. Tetrahedron Lett. 1991, 32, 5753 (b) Brown, R. F. C.; Choi, N.; Eastwood, F. W. Aus. J. Chem. 1995, 48, 185

(23) (a) Semmelhack, M. F. In Comprehensive Organometallic Chemistry II; Pergamon: Oxford, U.K., 1995; Vol. 12, p 979, p 1017. (b) Davies, S. G.; McCarthy, T. D. In Comprehensive Organometallic Chemistry II; Pergamon: Oxford, U.K., 1995; Vol. 12, p 1039. 